\title{
УПРАВЛІННЯ ОБМЕЖЕННЯМИ ІНТЕЛЕКТУАЛЬНО-РЕСУРСНОГО ПОТЕНЦІАЛУ ПРАЦІВНИКА НА ОСНОВІ ТЕОРІЇ ОБМЕЖЕННЯ СИСТЕМ
}

\author{
Перевозова I. В. д. е. н., \\ Тимошенко Д. В. к. е. н., \\ Кравчук Р. С. к. е.н.
}

Україна, Івано-Франківськ, Івано-Франківський наџіональний технічний університет нафти і газу

DOI: https://doi.org/10.31435/rsglobal_ijite/01062018/5663

\section{ARTICLE INFO}

Received 23 April 2018

Accepted 25 May 2018

Published 01 June 2018

\section{KEYWORDS}

intellectual and resource

potential,

intellectual resources,

management,

motivation,

theory of constraints

\begin{abstract}
The article deals with the analysis of the approach to managing business processes based on the concept of system constraints theory. The actual tasks concerning the management of an employee's intellectual resource in the context of operational management on the basis of the theory of system constraints are revealed. It was emphasized on the necessity of applying the methodology of TOC in order to manage the intellectual resources of a worker. The 5-step method of controlling worker restrictions on the basis of TOC is proposed. Formed proposals for the introduction of scientific research into the model of intellectual organization.
\end{abstract}

(C) 2018 The Authors.

Вступ. В сучасній практиці організації як особистісного розвитку, так i функціонального будь-кого індивіда відсутнє однозначне вирішення проблеми наявності перешкод для розвитку тіла, свідомості (а також душі і духу, які поки що перебувають у розділі феноменології сучасної науки) задля реалізації демографічного спектру потреб та повноцінного розвитку iі генетично обумовленого потенціалу. Натомість, робота в складних умовах сьогодення вимагає від людини-працівника арсеналу особистих та професійних якостей, навичок і компетенцій. Відсутність останніх призводить до формування низки управлінських обмежень (методика визначення обмежень Вудкока М. і Френсіса Д. [1]). Однак, самого визначення цієї деривації, наведеного в тексті і теоретично описаного, для розуміння проявів та оцінки практичного застосування є недостатньо. Потреба, а відповідно, і побудова адаптивного механізму управління цими обмеженнями, вимагає від науковців глибокого розуміння як їх природи і суті, так і оцінювання можливостей нівелювання.

Підприємство або організація є не лише соціально-економічною, але й технікоекономічною системою то стає зрозумілим, що розглядати елементи (підсистеми) організації (у нашому випадку - людину, як працівника) окремо недостатньо, адже «... окрім фізичних законів, існують закони людських систем.» [2, с. 18]. Опитувальник методики визначення обмежень хоч і містить достатній діапазон питань стосовно самоуправління, ціннісних орієнтацій, цілей, навичок поводження в конфліктних ситуаціях і навичок впливу, креативності тощо, він відіграє роль «статичного приладу виміру «температури» працівника» у той час як більшість підприємств/організацій вимагають динамічного методу розкриття потенціалу (талантів) працівників 3 можливістю його корекції. Ще 5 років тому HR-менеджери компанії Ібей (англ. eBay Inc) наголошували на тому, що «... довгострокова програма розвитку талантів (сама програма триває 8 місяців - примітка авторів статті) - неефективні інвестиції. Причина полягає в тому, що знання і компетенції, які набуваються до моменту завершення програми вже не потрібні компанії. Вже змінився світ, ринок, очікування клієнтів, бізнес-поведінка.» [3, c. 21]. I хоча складові тесту разом з його результатами відображають дуалізм розвитку (або ж ентропії) пари «організація-працівник» і навіть свідчать про наявність або відсутність успішності соціально-економічної системи, вони не відображають динамічних змін інтелектуально-ресурсного потенціалу працівника в контексті мінливості середовища 
діяльності підприємства (як внутрішнього, так і зовнішнього). Окрім того, сучасна організаційна система підприємства/організації вимагає не стільки констатації свого відображення у працівниках, скільки можливості впливати на них.

Таким чином, невирішена раніше частина загальної проблеми управління персоналом, якій присвячується дана праця, полягає у винайдені оптимального комплексу управлінських впливів керівника $(K У B \kappa)$ на процес розвитку працівником свого інтелектуально-ресурсного потенціалу $(I R P)$ в контексті організаційної системи в напрямку необхідних для підприємства компетенцій з подальшим унеможливленням виникнення «вузьких місць» — обмежень.

Результати дослідження. До управління підприємством слід підходити цілісно і системно, що передбачає розгляд усіх частин системи у тісній взаємодії. Лише цей підхід здатен адекватно відобразити у свідомості людини-працівника мету, цілі і цінності соціальноекономічної системи, забезпечуючи зворотній зв'язок з соціальною, фінансово-економічною, технічною, технологічною, організаційно-управлінською, маркетинговою, інформаційною та іншими підсистемами підприємства. Це сприяє реалізації «організаційної гідравліки» [4, с. 14] - поняття, що позначає переведення корпоративних цілей у дії окремо взятого працівника. Разом із цим системний підхід також вказує на наявність обмежень, тісно пов'язаних 3 професіоналізмом, який у свою чергу, має пряме відношення до компетенцій працівника i, як не дивно, «ключових компетенцій» підприємства [5]. Концепція останніх запропонована Прахаладом С. та Хемелом Г., які рекомендують компаніям після проходження відповідного аудиту, який охоплює організаційні знання, технології, HR-менеджмент, стосунки та унікальну атмосферу у колективі (яку, на відміну від бізнес-моделі, неможливо скопіювати) займатись усім тим, що їх персонал вміє робити найкраще. В цілому, ключові компетенції визначаються як навички та вміння персоналу підприємства, які стають запорукою успішної конкуренції [6]. Таким чином, «<..> ключовою називається компетенція вищого порядку <...>, яка являється колективним знанням, що дозволяє організовувати i управляти використанням інших компетенцій і здатностей ...» [7]. Алгоритміка сучасного управління полягає у ідентифікації ключового та забезпечувального бізнес-процесів [8]. Таким чином, ключовий бізнес-процес, окрім своїх основних функцій при належній ліквідації обмежень у використанні людиною свого інтелектуально-ресурсного потенціалу, у т.ч. шляхом застосування сучасних механізмів мотивації - комплексу управлінських впливів керівника $(K У B \kappa)$, «... оптимізує усі підрозділи організації за принципом тандему інтелектуальної діяльності, а забезпечувальний забезпечить діяльність даного тандему шляхом організації командної взаємодії.» [8, с. 156]. Дану оптимізацію пропонується провести в контексті використання елементу нової парадигми управління організацією — всесвітньовідомої теорії обмежень систем (ТОС, англ. Theory of Constraints), яка здатна виявити і усунути усі обмеження або «вузькі місця» на підприємстві.

Наукові дослідження усього конфронтаційного, негнучкого, ворожого і такого, що перешкоджає наближенню працівника як найціннішого активу сучасної соціально-економічно системи до «серця справжнього життя» в контексті організаційного середовища часто розглядається $з$ позиціі:

1) загальної психологї у т.ч. менеджменту персоналу і загальної теорії управління (Бесчасний Л., Богиня Д., Буян І., Врублевський В., Гош А., Кваснюк В., Корнієнко В., Кривенко К., Логвиненко В., Лукінов І., Мочерний С., Нестеренко В., Пахомов Ю., Петренко В., Рубан А та ін.). Західна теорія менеджменту завдячує таким економістам, соціологам, психологам та іншим спеціалістам в галузі управління людським ресурсами, як Альберт Х., Браун I., Гелбрейт Д., Герцберг Ф., Грейсон Д., Друкер П., Зіберт В., Ланг Л., Макгрегор Д., Маслоу А., Мейо Е., Файоль А. та ін.);

2) впливу соціально-психологічних чинників на професіоналізм вітчизняними авторами: Гришина М., Деркач А., Дружилов С., Карамушка Л., Коротков Е., Кузьміна Н., Маркова А., Нікіфоров Г., Сорочан Т., Шепель В., а також іноземними авторами - Альберт М., Армстронг М., Вейл П. Гудсон І., Мескон М., Паскаль П., Равен Дж., Уінтертон Дж., Фуллан М., Харгріверс Е.

3) безпосередньо обмежень і теорії систем: Зіновєв Ф., Пакк Х. Павловська Н., Попадинець I. Р., Устенко А. та ін.

В основу класифікації обмежень працівника можуть бути покладені різноманітні ознаки. Так, Вудкок М. та Френсіс Д. щодо визначення обмежень в управлінні визначають 11 чинників-перешкод, які здійснюють вплив на ефективність управлінської діяльності: 1) невміння управляти собою; 2) розмиті особисті цінності 3) несформовані особисті цілі; 4) зупинений саморозвиток; 5) низький рівень навиків у вирішення проблеми; 6) низький рівень 
творчого підходу; 7) невміння впливати на оточуючих; 8) недостатне розуміння особливостей управлінської праці; 9) невміння управляти; 10) невміння навчати; 11) низька здатність формувати колектив [1]. Зіновієв Ф. [9, с. 269] групує обмеження в діяльності менеджера за ознакою позиціювання відносно особи фахівця:

1) зовнішні умови: політичні, регіональні, соціальні, економічні, національні;

2) потенціал фахівця: інтелект, досвід, вік, кваліфікація менеджера, розуміння можливостей;

3) внутрішні умови: кваліфікація фахівців, технічне, фінансове, інформаційне, методичне, програмне забезпечення.

Обмеження можуть також мати і гендерну ознаку [10], а також і проявляти себе в контексті умов глобалізації [11] тощо.

На наш погляд, дану проблематику слід досліджувати з метою ліквідації (або нівеляції впливу) з використанням системного підходу.

Сукупність та варіативність комбінаторного об'єднання елементів підприємства утворюють окремі структурні одиниці: підсистеми управління (суб'єкти) і керовані підсистеми (об'єкти). Так, підсистема - це окрема система, яка має властиві їй ознаки, цільову орієнтацію, притаманні принципи функціонування, але в даний момент виступає складовою відносно незалежною частиною системи вищого порядку. Якщо ж частина системи таких властивостей не має, а просто $є$ сукупністю однорідних елементів, то їх називають компонентами [12].

Здійснення управлінського впливу, тобто зміна стану об'єкта, завжди пов'язане із інформацією, яку отримує суб'єкт і яка впливає на його потребу щодо об'єкта. Зазначимо, що поняття системи $€$ надзвичайно складним. Існує кілька десятків його визначень. За М. Булатовим, система - це «зовнішнє або внутрішнє впорядкування сукупності знань, а також метод аналізу об'єктів як цілісних утворень» [13, с. 449].

Система за своєю суттю є сукупністю елементів, що є взаємопов'язаними і взаємодіють між собою, утворюючи одне ціле задля досягнення спільної мети. Переміщення усіх елементів Системи в часі і просторі спричиняє їх постійну зміну в напрямку прогресу чи регресу. Це спричиняє зміну людини як складної системи як в контексті свого его - «..особистих інтенцій, біологічних імперативів та культурних кодів ...» [14, с. 33], так і зміну людини в контексті самої системи, що в кінцевому рахунку, є прикладом класичної дихотомії, як послідовного ділення цілого на частини, які більше пов'язані між собою всередині, аніж ззовні. Дослідження об'єкту часто вимагає його деконструкцію що є розкладанням останнього на складові частини. Досліджуючи один елемент ми можемо отримати відомості як про систему в цілому, так і про конкретний стан їі елементу.

ТОС є креатурою Голдратта Е., яка починає розвиватись з 1970-х років ХХ століття [15-19]. Вона ілюструє підприємство/організацію як систему, яка функціонує як один довгий ланцюг. На прикладі цього Голдратт Е. якнайкраще демонструє нам поняття взаємозалежних елементів підприємства. Міцність ланцюга залежить від того яке навантаження здатна витримати його найслабша ланка у порівнянні $з$ іншими. Дану аналогію слід перенести на ціле підприємство найслабше місце підприємства Голдратт Е. називає системним обмеженням [18].

Для ліквідації слабкості цілого ланцюга найслабшу ланку ремонтують. Після іiі зміцнення міцність цілого ланцюга зростає, але лише до певної межи - до того часу, коли наступна ланка послабне від напруги і почне своїм незадовільним станом загрожувати міцності цілому ланцюгу. Аналогічно і з підприємством: до прикладу, проблема поганої логістики уповільнює рух складального конвеєру. Доки цей елемент не буде відремонтовано шляхом підвищення його пропускної здатності, будь-які інші маніпуляції з покращення нашої «слабкої ланки» здійснювати марно [19].

ТОС є вельми прогресивним елементом нової парадигми управління підприємством, адже уважна концентрація на проблемі дозволяє перетворити останню у задачу з подальшою реалізацією чіткого алгоритму управлінських дій щодо усунення «вузького місця». Але й це ще не все: цінність теорії підкріплюється тим, що ліквідація «вузького місця» при відповідному заглибленні у суть задачі здатне оголити інші недоліки організаційної системи, які пов'язані з менеджментом, маркетингом, виробництвом тощо. У колективній праці [20] зазначено, що ми можемо мати справу 3 декількома обмеженнями одночасно, однак, «<..> їх завжди буде невелика кількість.» [20, с. 200]. Інше трактування підходу Голдратта Е. полягає у тому, що « $<.>$ в кожен конкретний момент часу в системі є тільки одне обмеження.» [21, с. 82]. Вражаємо, що обидва методи заслуговують право на життя, оскільки провадження аналізу потребує концентрації значної уваги. 
На операційному рівні методологія ТОС оперує трьома показниками: «... усе, що ви робите на заводі підпадає під ці три визначення.» [15, с. 89]:

1) «Прохід» (англ. Throughput) - як «... швидкість, 3 якою система генерує гроші в результаті продажів.» (курсив автора, Голдратта Е.) [15, с. 87]. Одразу зауважимо на принциповості погляду автора щодо переваги продаж над виробництвом: «... В результаті продаж, а не виробництва. Якщо ти щось виробив, але не продав, це не прохід.» [15, с. 87]. Інакше кажучи, «... це гроші, які система генерує в результаті продаж, за вирахуванням повністю змінних прямих витрат на одиницю виробленої продукції ...» [15, с. 87].

2) «Товарно-матеріальні цінності» (в інших джерелах фігурує під назвою «Інвестиції» від англ. Investment) — це, умовно кажучи, гроші, які розширюють Прохід (вкладені в обладнання, будівлі, споруди, землю, сировину, готову продукцію тощо). За визначенням Голдратта Е. це «... загальна сума грошей, інвестована системою у купівлю того, що вона намагається продати у кінцевому рахунку.» [15, с. 88].

3) «Операційні витрати» (англ. Operational Expenses) — «... це загальна сума грошей, витрачена системою на переведення товарно-матеріальних цінностей у прохід.» [15, с. 88]. Це усі інші витрати організації окрім прямих змінних.

Мистецтвом ТОС є скорочення операційних витрат і товарно-матеріальних цінностей — «інвестицій» (інакше кажучи потрібно «віддавати менше грошей») вкупі зі збільшенням «проходу». Зрозуміти дане міркування допомагає ремарка Голдратта Е. стосовно того, що «<..> завод, на якому усі весь час працюють — це дуже неефективний завод» [15, с. 119], оскільки останній сприяє зростанню залишків через надмірне використання робочої сили. Це витягує усі «живильні соки» соціально-економічної системи, знищуючи їі здоров'я та гальмуючи iї розвиток в усіх напрямках, у т.ч. в напрямку генерування інтелектуальної продукції і інновацій в цілому. Цікаво, що даний приклад може ілюструвати не лише класичний завод - звуження проходу призводить до втрат фінансів на обслуговування і зберігання як матеріальних об’єктів на складах (сировина), так і нематеріальних об’єктів - незатребуваних патентів, ліцензій, підтримка яких пасивно витягує гроші. Для уникнення таких проявів доцільне застосування концепції реінжинірингу бізнес-процесів (РБП) [22], що має на меті оптимізацію усіх процесів організації в просторі і часі, у т.ч. шляхом відсікання усіх непрофільних активів і зменшення нераціональних пауз. Не входячи у розбіжності 3 РБП, засновник концепції ТОС наголошує на тому, що «<..> збалансований завод < ..> - це завод, на якому потужність усіх ресурсів до одного повністю збалансована 3 ринковим попитом» $[15$, с. 120]. Такий підхід сприяє «вирівнюванню тиску» у «загальноорганізаційній «трубі», що унеможливлює виникнення «вузького місця».

Для усунення обмежень в управлінні підприємством пропонується методика [21], яка алгоритмізована і поглиблена авторами в прикладному аспекті (рис.1). Варто наголосити, що «вузьким місцем» може бути що завгодно: цех, несправне або неправильно налаштоване обладнання, погане постачання сировини, або, як не дивно окрема особа (або група осіб). Це означає, що обмеження можуть бути як фізичними, так і управлінськими.

Перші просто блокують збільшення продуктивності. Другі «.. - це стереотипи i переконання, які ніхто не ставить під сумнів. Вони складають 90-95 \% усіх обмежень» [21, с. 82]. Подібний спосіб мислення сприятиме деградації управлінських навичок 3 появою «репресивної» культури мислення [23]. Саме тому проблема виробничої логістики $з$ 1970-х «вперлась в людину» $\mathrm{i}$ поступово перетворюється на загальних шлях мислення (парадигму) і технологію розумового процесу, який дає відповіді на питання чому окремий працівник або група працівників також можуть бути «шийкою від плішки» - найслабшою ланкою в системі управління, яка іноді свідомо здатна занижувати результативність своєї праці, саботувати роботу і активно (або латентно) демонструвати усі інші види непокори. Тому дана ланка потребує надмірної уваги в контексті оптимізації як основного так і забезпечувального бізнес-процесів.

Важелем для підйому системи в контексті використання концепції ТОС є робота 3 інтелектуальним ресурсом особи або групи осіб. Дослідженню останнього присвячена значна низка праць, однак зауважимо, що поняття інтелектуального ресурсу є характеристикою, що притаманна кадровим ресурсам організації [24], що належать до поняття «трудові ресурси» це «... відносини розширеного відтворення фізичних і розумових здібностей, знань, навичок та інших якостей людей, необхідних їм для роботи в народному господарстві, всебічного розвитку працівників у процесі суспільного виробництва» [25, с. 696]. Саме їм притаманна властивість «... розширеного відтворення фізичних і розумових здібностей, знань, навичок ...», що можна вважати соціальною поведінкою. Джерелом цієї поведінки $є$ «... мотиваційна система 
особистості, або мотивація - межовий вияв структури особистості, яка діє або поводиться певним чином на перетині суб'єктивних (внутрішніх) сил і об'єктивних (зовнішніх) факторів.» [25, с. 696]. Усе це має досліджуватись в контексті такого поняття як «... фонд часу, які має система для реалізації мети, задля якої вона існує.» [25, с. 208].
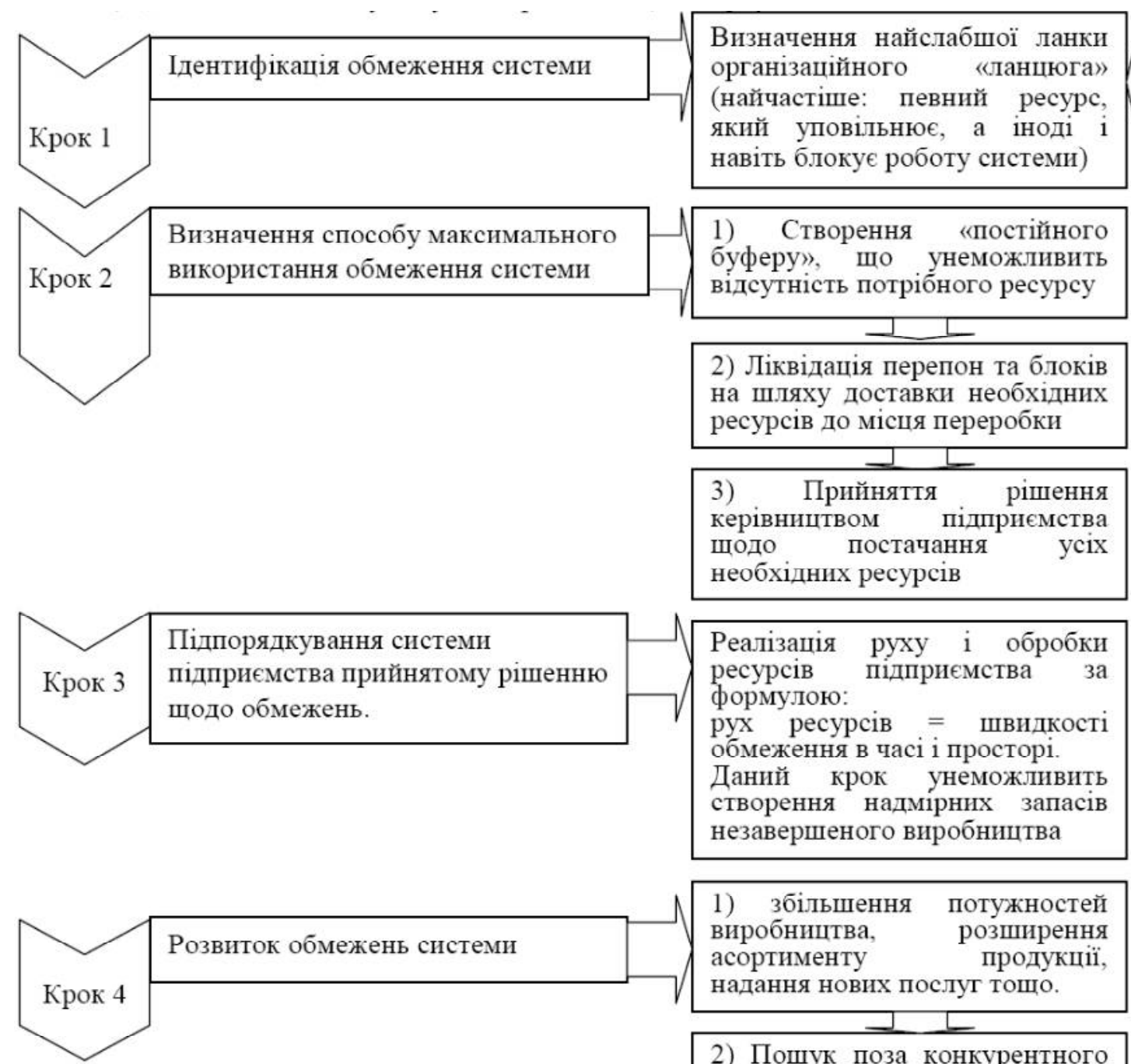

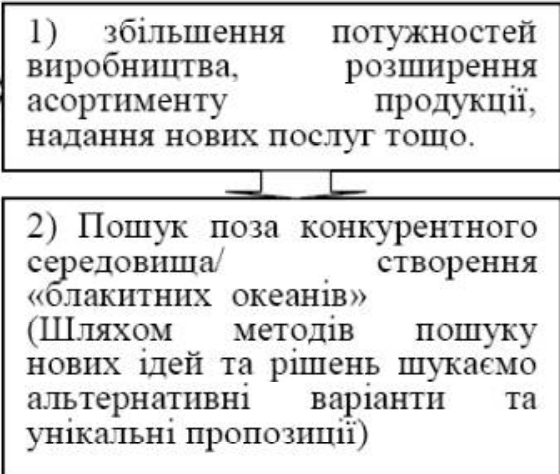

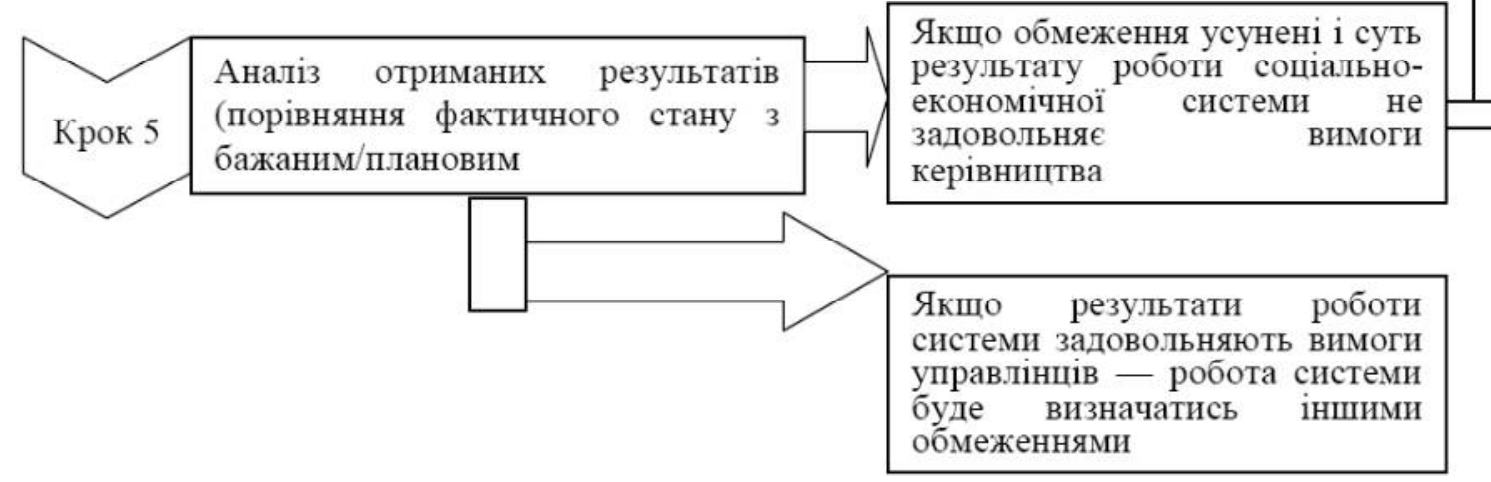

Рис. 1. Візуалізація алгоритмізованої методики усунення обмежень при управлінні Джерело: Розроблено авторами на основі [21] підприємством 
Таким чином, нехай $з$ вищевказаного важливо те, що «... розумові здібності, знання і навички ...» стануть нічим іншим як характеристикою рівня інтелекту особи - $L_{I P}$; «... інші якості людини, необхідні їй для роботи в народному господарстві ...» можуть активізуватись і діяти лише в контексті «мотиваційної системи особистості» - $M_{I P}$, а «... для реалізації мети, задля якої вона існує ...» шляхом ефективного використання власного інтелекту слід використати фонд часу, який особа має в розпорядженні - $T_{I P .}$ В першому наближенні можна стверджувати, що «інтелектуальний ресурс особи» $(I R P) \epsilon$ функцією трьох вищеназваних чинників [24, с. 253]:

$$
I R P=F\left(L_{I P}, M_{I P}, T_{I P}\right)
$$

де $L_{I P}$ - рівень інтелекту; $M_{I P}$ - рівень мотивованості особи до ефективного використання власного інтелекту; $T_{I P}$ - тривалість ефективного використання особою власного інтелекту.

Врахування всіх трьох чинників при визначенні IRP є обов'язковим. При відсутності хоча б одного поняття «інтелектуальний ресурс особи» втрачає сенс. Низький рівень інтелекту $\left(L_{I P}=0\right)$, демотивована поведінка $\left(M_{I P}=0\right)$ або ж відсутність ресурсу часу $\left(T_{I P}=0\right)$ унеможливлює прояв мотивованого, цільового і ефективного інтелектуального ресурсу $(I R P=$ $0)$. При $L_{I P}>0, M_{I P}>0$ і $T_{I P}>0$ людина утворює певний особистісний інтелектуальний ресурс,який є ефективним (IRP $>0)$. Під визначенням IRP пропонується розуміти «... комплекс набутих особою розумових здібностей, знань i навиків, а також мотивів та часу для їх ефективного використання, який оцінюється сукупними витратами для їх набуття i розширеного відтворення.» [24, с. 255]. Графічна інтерпретація інтелектуального ресурсу особи як функції рівня інтелекту, вмотивованої поведінки і ресурсу часу вперше була запропонована у науковій праці [26, с. 7] та дістала подальший розвиток у праці [27]. Остання представлена нижче де показані точки мотиваційної і інтелектуальної біфуркації (рис. 2).

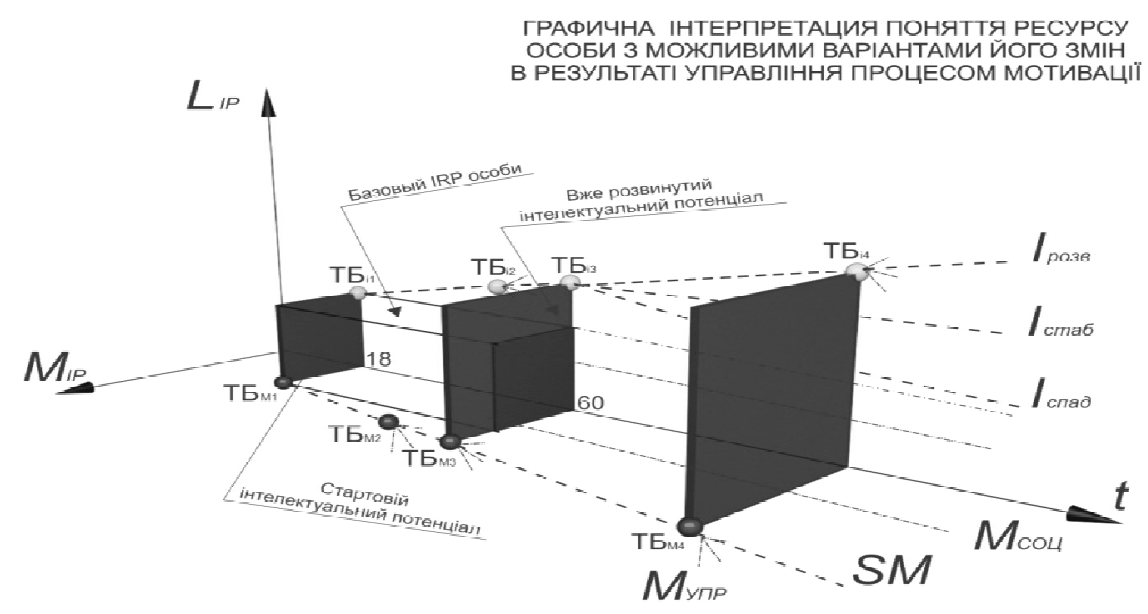

Рис. 2. Графічна інтерпретація поняття інтелектуального ресурсу особи з можливими варіантами його змін в результаті управління процесом мотивації [26, с. 7$]$

Взято до уваги, що будь-яка особа починає працювати в соціально-економічній системі в економічно активному віці (18-20 років). Вже тоді людина має в наявності певний рівень початкового інтелекту $\left(L_{I P S}\right)$ і мотивації $\left(M_{I P S}\right)$. Останні сформовані соціумом шляхом навчання i виховання. Особа має стартовий інтелектуальний потенціал. Він визначається площею прямокутника в площині $L_{I P S}-M_{I P S}$. На початку економічно і соціально активного життя людини розташовані точки потенційної інтелектуальної $\left(T 5_{i 1}\right)$ та мотиваційної $\left(T Б_{м 2}\right)$ біфуркації. Точки демонструють потенційно можливі зміни iii iнтелектуальних i/aбо мотиваційних характеристик. Мета управління IRP працівника — створити умови для появи (імпульс) i початку дï (направленого руху) таких точок по «коридору» IRP працівника протягом всього службового. При цьому, «... під точкою інтелектуальної біфуркації $\left(T \zeta_{i 1}\right)$ 
розуміється момент початку змін інтелектуального потенціалу особи, причиною яких $є$ дія нових знань, нового досвіду, нових обов'язків і відповідальності, а під точкою мотиваційної біфуркації $\left(T Б_{м 2}\right)$ - момент початку змін інтелектуального потенціалу особи, причиною яких $\epsilon$ дія спеціально запроектованих i реалізованих мотиваційних впливів керівництва i/aбо іiі внутрішньої самомотивації.» [26, с. 8]. В змінах інтелектуального потенціалу людини присутні і інтелектуальні складові. Ними є нові знання, новий досвід, навички, вміння, новий статус, нові обов'язки, нова відповідальність. У просторовій моделі присутні також і психологічно-емоційні складові - самомотивація особи $(S M)$ і зовнішня мотивація особи керівництвом (Mynp).

Сенс життя будь-якої людини полягає у їі розвитку. Під цим розуміємо розвиток іï стартового інтелектуального потенціалу.

Протягом роботи особи в соціально-економічній системі різними методами i механізмами формуються наступні точки інтелектуальної біфуркації: $T Б_{i 2}$ (отримання, накопичення і використання досвіду практичної роботи, зміна посади або обов'язків) $\rightarrow T Б_{i 3}$ (досягнення пенсійного віку) $\rightarrow T Б_{i 4}$ (досвід пенсійного життя) та ін. Таким чином, в моменти їх виникнення «... починається дія впливів, які будуть приводити до змін в інтелектуальному потенціалі особи $L_{I P}-M_{I P} 3$ відповідними наслідками в змінах іiі інтелектуально-ресурсного потенціалу. Позитивний або негативний напрямок цих змін залежить від стану мотивації особи, тобто комплексного впливу трьох складових Mcou, Mynp i SM. Комплексна позитивна мотивація за всіма вказаними складовими спричиняє зростання $I R P$, а відсутність або негативна спрямованість і вплив будь-якої із цих складових — його зменшення. 3 цих позицій, увага, звернена на вчасну розробку і впровадження мотиваційних заходів, якщо не зі сторони соціуму, то хоча б зі сторони керівництва і особи, що забезпечить якщо не зростання, то, принаймні, стабілізацію інтелектуального потенціалу та IRP особи в контексті певної системи.» [26, с. 8]. Сучасний управлінець повинен розвивати як базові, так спеціальні компетенції - ті знання, уміння i навички, що дозволяють досконально визначити стратегію розвитку компанії, спираючись на три складові інтелектуального ресурсу особи: «... рівень інтелектуального потенціалу особи ...», «... рівень мотивації особи ...» і «... фонд часу ...», який особа має для використання [24, с. 253].

На основі графічної інтерпретації поняття інтелектуального ресурсу особи з можливими варіантами його змін в результаті управління процесом мотивації було побудовано модель сучасного менеджера, орієнтованого на пріоритетне використання інтелектуальної праці [27], що є продовженням серії авторських досліджень в галузі побудови моделі організації на основі механізму інтелектуальної мотивації працівників [14]. Отримана у даній праці у вигляді гіперкубу (тесеракту) модель здатна живити своєю енергією працівників, спричиняючи їхню мотиваційну i інтелектуальну біфуркацію. До того ж дана модель також виступає продовженням наукових розвідок у сфері управління інтелектуально-ресурсним потенціалом працівника $(I R P)$. Також містить необхідне інформаційне забезпечення для переміщення точок інтелектуальної та мотиваційної біфуркації у потрібному напрямку. Це що забезпечить гармонійне розширення «коридору розвитку» людини. Аналогією цього, в нашому випадку, виступає поняття «Прохід» (англ. Throughput), що запропонований автором ТОС у [15]). Що до іншого важливого компоненту ТОС — «Товарно-матеріальних цінностей» (англ. Investment), тобто грошей, що розширюють «Прохід» (вкладені в обладнання, будівлі, споруди, землю, сировину, готову продукцію тощо), які визначаються як «... загальна сума грошей, інвестована системою у купівлю того, що вона намагається продати у кінцевому рахунку.» [15, с. 88]. Тут слід припустити, що кожну із складових інтелектуально-ресурсного потенціалу особи - $L_{I P}$, $M_{I}, T_{I P}$ можна оцінити понесеними на iї формування і підтримання певними витратами. Формула для визначення обсягу витрат, що є необхідних для формування всіх складових IRP $\left(L_{I P}, M_{I}, T_{I P}\right)$, може мати наступний вигляд [24, с. 254]:

$$
C_{\Sigma}=\sum_{i=1}^{n} \sum_{j=1}^{t} C_{i j},
$$

де $C_{\Sigma}$ - сукупні витрати на отримання освіти, життєвого i професійного досвіду (формування, розвиток, накопичення), самомотивацію і мотивацію (використання), охорону здоров'я і здоровий спосіб життя (підтримання і збереження) інтелектуального ресурсу особи; $C_{i j}-$ витрати $i$-го виду, пов'язані з оплатою всіх названих вище дій, які здійснюються протягом $j$-го року; 
$n$ - кількість видів витрат, понесених особою на здобуття всіх складових, які приймають участь у формуванні чинників $L_{I P}, M_{I P}$ та $T_{I P} ; t$ - тривалість періоду витрат $i$-го виду.

«Операційні витрати» (англ. Operational Expenses) під якими розуміється «... загальна сума грошей, витрачена системою на переведення товарно-матеріальних цінностей у прохід.» [15, с. 88] в нашому випадку найбільш відповідають складовим у вигляді витрачених на їх формування коштів. Формула для економічної оцінки інтелектуального ресурсу окремої особистості $(E E P)$, «... як джерела і засобу забезпечення процесу виробництва й розширеного відтворення, в найбільш узагальненому випадку буде мати наступний вигляд» [24, с. 255]:

$$
E E P=C_{\Sigma}+m C_{\Sigma}=C_{\Sigma}(1+m)
$$

де $m$ - середня норма прибутку на сукупні витрати, тобто, вкладених в розвиток особи інвестицій. При цьому, джерелами інвестування виступають сімейні, місцеві і державний бюджети, кошти підприємств, установ та організацій, спеціальних фондів тощо [24].

Висновки. Отже, акцентування уваги на людських ресурсах в ході будь-якої оптимізації соціально-економічної системи; необхідності оптимізації людських ресурсів в контексті системного підходу, а саме - за допомогою ТОС, а також виділенні інтелектуального ресурсу особи задля візуалізації цілі управління, $є$ питаннями, що актуалізовані сучасністю: покоління молодих людей як майбутніх працівників - виконавчих елементів соціально-економічної системи і складової частини людського капіталу не зацікавлено у підтримці існуючої моделі світового порядку постіндустріальної економіки, яка, не дивлячись на свою філософію використання IV фактору виробництва - інтелекту, все ще продовжує існувати в жорстких умовах «... вуглеводних деспотій ...», так і «... трубопровідних демократій ...» $[28$, с. 149.] і характеризується небажанням сучасних еліт (політиків, юристів, фінансистів і бюрократів в цілому) позбуватися існуючих привілеїв.

Відтак, проблемою у загальному вигляді постає наявність організаційних перешкод для розвитку тіла, свідомості (а також душі і духу, які поки що перебувають у розділі феноменології сучасної науки) задля реалізацію особою демографічного спектру потреб та повноцінного розвитку її генетично обумовленого потенціалу, що досягається лише в контексті теперішніх організацій.

На підставі удосконаленої авторами алгоритмізованої методики усунення обмежень при управлінні підприємством, що наведена в даній статті, в продовження досліджень буде контуроване іiі застосуванння як для виявлення «вузьких місць» у використанні людиною власного IRP, так і управління ним.

\section{ЛІТЕРАТУРА}

1. Вудкок М. Раскрепощенный менеджер. Для руководителя-практика [Текст] / M. Вудкок, Д. Френсис ; пер. с англ. - М. : Дело Лтд, 1994. - 320 с.

2. Мартынов А. Жизнь в условиях турбулентности [Текст] / А. Мартынов // Комп\&ньон. - 2010. - № 13. - С. 18.

3. Логвиненко А. Будущее, в котором мы уже живем [Текст] / А. Логвиненко // \&.СТРАТЕГИИ. - 2014. — № 11-12. - С. 20-23.

4. Салл, Д. Готовы ли вы к восстановлению? Семь вопросов руководителю [Текст] / Д. Салл // \&.СТРАТЕГИИ. - 2010. — № 4. - С. $10-18$.

5. Prahalad, C. The core competence of the corporation [Text] / C. Prahalad, G. Hamel // Harvard Business Review. - 1990. — № 3 (68). — C. 79-91.

6. Хэмел Г. Стратегическая гибкость [Текст] / Г. Хэмел, К. Прахалад и др. - СПб. : Питер, 2005. - 384 с.

7. Ключевые компетенции. Marketopedia. Онлайн энциклопедия маркетинга [Електронний ресурс]. - Режим доступу до сайту: http://marketopedia.ru/40-klyuchevyekompetencii.html, вільний (дата звернення: 10.05.2018). - Заголовок з екрану. - Мова рос.

8. Тимошенко Д. В. Організація командної взаємодії як ключова компетенція вищого порядку [Текст] / Д. В. Тимошенко // Економічний вісник університету (Збірник наукових праць учених та аспірантів). Вип. 22 (2) / Переяслав-Хмельницький державний педагогічний університет імені Григорія Сковороди. Редкол.: голов. ред. Т. М. Боголіб. - ПереяславХмельницький, 2014. - С. 153-157. 
9. Зінов `в Ф. В. Нормування і оцінка управлінської праці [Текст] / Ф. В. Зіновєв // БІЗНЕС-НАВІГАТОР. — 2013. - № 3. - С. 269-273.

10. Кот Г. М. Гендерні особливості психологічної підготовки керівників навчальних закладів [Текст] / Г. М. Кот // Вісник Національного авіаційного університету. Серія: Педагогіка, Психологія. - 2010. - № 3. - С. 38-43.

11. Васечко Л. Обмеження прав людини в умовах глобалізації: проблеми теорії $\mathrm{i}$ практики [Текст] / Л. Васечко // Юридична Україна. - 2013. - № 1. - С. 4 -8.

12. Кендюхов О. В. Економічний підхід до вивчення часу / О. В. Кендюхов, К. Ю. Ягельська // Маркетинг і менеджмент інновацій. - 2012. - № 3. - С. 141-148.

13. Булатов М. О. Філософський словник / М. О. Булатов. - К. : Стилос, 2009. -575 с.

14. Тимошенко Д. В. Деякі міркування про побудову структури сучасної інтелектуальної організації [Текст] / Д. В. Тимошенко // Инновационные технологии управления. В 2 книгах. К 1. : монография / [авт.кол. : Баранников А.А., Дунская А.Р., Ильиных С.А. и др.]. - Одесса: КУПРИЕНКО СВ, 2013 - С. 32-49.

15. Голдратт Э. Цель. Процесс непрерывного улучшения. Цель-2. Дело не в везенье [Текст] / Элия М. Голдратт, Джефф Кокс. ; пер. с англ. Е. Федурко. Редактор Х. Пакк. - К. : ИД «Максимум», 2008. - 778 с.

16. Голдратт Э. Цель - 3. Необходимо, но не достаточно [Текст] / Голдратт Э., Шрагенхайм Э., Птак К. ; пер. с англ. Д. Капранов. - К. : НіД, 2009. — 243 с.

17. Голдратт Э. Критическая цепь [Текст] / Э. Голдратт ; [пер. с англ. Е. Федурко]. М. : ТОС центр, 2007. — $272 \mathrm{c.}$

18. Детмер У. Теория ограничений Голдратта: системный подход к непрерывному совершенствованию. — 2-е изд. [Текст] / У. Детмер ; [пер. с англ. У. Саломатова ; под ред. Ю. Быстрова]. - М. : Альпина бизнес букс, 2008. - 444 с.

19. Детмер У. Производство с невероятной скоростью. Улучшение финансовых результатов предприятия [Текст]/ У. Детмер, Э. Шрагенхайм ; пер. с англ. О. Наливайко. - М. : Альпина-паблишерз, 2009. - 329 с.

20. Кримська Л. О. Управління підприємством на основі теорії обмежень [Текст] / Л. О. Кримська, О. О. Шевченко // Бізнес інформ. — 2012. — № 12. - С. 198-201.

21. Михайлишин Н. П. ТОС - теорія, що ламає стереотипи [Текст] / Н. П. Михайлишин, Н. Г. Мельник // Сталий розвиток економіки. Хмельницький : Інститут економіки і підприємництва. - 2011. — № 4 (7). - С. $81-83$.

22. Хаммер М. Реинжиниринг корпорации : Манифест революции в би знесе [Текст] / М. Хаммер, Дж. Чампи; пер. с англ. Ю. Е. Корнилович. - М. : Манн, Иванов и Фербер, 2006. $-287 \mathrm{c}$.

23. Булгаков М. А. Собрание сочинений. В 5-ти т. Т. 2. Дьяволиада; Роковые яйца; Собачье сердце; Рассказы; Фельетоны [Текст] / Редкол.: Г. Гоц, А. Караганов, В. Лакшин и др. Подгот. Текста и коммент. В. Гудковой и Л. Фиалковой. - М.: Худож. лит., 1989. - 345 с.

24. Василишина Н. Є. До уточнення поняття «інтелектуальний ресурс» 3 метою адекватної оцінки і врахування в процедурах стратегічного планування економічного розвитку регіональних соціально-економічних систем [Текст] / Н. Є. Василишина, Д. В. Тимошенко, І. В. Фіщук, В. П. Петренко // Соціально-економічні дослідження в перехідний період. Інноваційноінвестиційне забезпечення стратегії розвитку регіону (Збірник наукових праць). Вип. 5 (61) / НАН України. Ін-т регіональних досліджень. Редкол.: відп. ред. акад. НАН України М. І. Долішній. - Львів, $2006-$ С. 250-258.

25. Економічна енциклопедія: У трьох томах. Т.3 [Текст] / Редкол.: ... С.В. Мочерний (відп. ред.) та ін. — К. : Видавничий центр «Академія», 2002. — 952 с.

26. Тимошенко Д. В. Мотиваційний механізм управління інтелектуальною працею персоналу нафтогазових підприємств та організацій : автореф. дис. ... канд. екон. наук : 08.00.04 [Текст] / Д. В. Тимошенко. - Івано-Франківськ, 2011. - 20 с.

27. Тимошенко Д. В. Модель сучасного менеджера як інструмент розвитку його інтелектуально-ресурсного потенціалу [Текст] / Д. В. Тимошенко // Перспективные тренды развития науки: менеджмент, юриспруденция.: монография / [авт.кол. : Берлявский Л.Г., Кочеткова О.В., Орлов М.М. и др.]. — Одесса : КУПРИЕНКО СВ, 2016. — С. 68 -92.

28. Пелевин В. О. Ананасная вода для прекрасной дамы [Текст] / В. О. Пелевин. - М. : Эксмо, 2011. - 352 с. 